\title{
Pelatihan Menulis Puisi Dengan Media Gambar Pada Siswa Kelas VII SMP Negeri Kota Baru Kefamenanu
}

\author{
Joni S. Nalenan ${ }^{1)}$ \\ Program Studi Pendidikan Bahasa dan Sastra Indonesia \\ Fakultas Keguruan dan Ilmu Pendidikan Universitas Timor, Indonesia ${ }^{1)}$ \\ Pos-el : joninalenan07@gmail.com
}

\begin{tabular}{|l|l|l}
\hline Dikirim: 08, 06, 2020 & Direvisi: 06, 07, 2020 & Diterbitkan: 31, 08,2020
\end{tabular}

\begin{abstract}
Abstrak
Kegiatan pengabdian pada masyarakat ini berjudul "Pelatihan Menulis Puisi dengan Media Gambar pada Siswa Kelas VII SMP Negeri Kota Baru Kefamenanu". Kegiatan ini bertujuan untuk: memberikan pengetahuan dan penjelasan kepada siswa di SMP Negeri Kota Baru Kefamenanu mengenai menulis puisi dengan media gambar;memberikan pengetahuan dan penjelasan kepada siswa di SMP Negeri Kota Baru Kefamenanu mengenai langkah-langkah menulis puisi dengan media gambar;meningkatkan kreativitas siswa di SMP Negeri Kota Baru Kefamenanu dalam menulis puisi dengan media gambar; dan memotivasi siswa akan pentingnya menulis dan mengembangkan karya sastra berupa puisi.Khalayak sasaran dalam kegiatan pengabdian ini adalah siswa/siswi SMPN Kota Baru yang berjumlah 30 orang. Pelatihan Menulis Puisi dengan Media Gambar pada Siswa Kelas VII SMP Negeri Kota Baru Kefamenanu dilakukan dengan metode ceramah dan latihan/praktik. Metode ceramah digunakan untuk menjelaskan materi berupa hakikat puisi dan menulis puisi. Metode latihan digunakan untuk mempraktikkan menulis puisi dengan hasil pengamatan media gambar yang disajikan.Antusiasme peserta, dukungan kepala sekolah, wakil kepala sekolah, serta guru pendamping terhadap pelaksanaan kegiatan dan dana dari LPPM merupakan pendukung terlaksananya kegiatan pengabdian ini. Secara keseluruhan, kemampuan siswa kelas VIII SMPN Kota Baru dalam menulis puisi khususnya melalui media gambar cukup baik dengan rerata nilai 67.
\end{abstract}

Kata Kunci: menulis, puisi, menulis puisi, dan media gambar.

\begin{abstract}
The dedication entitled "The Training of Poetry Writing using picture to Grade Seven of SMPN Kota Baru Kefamenanu”. This activity aimed to provide knowledge and explaination to students in SMPN Kota Baru Kefamenanu about the procedure to create a poetry using picture; improve students' creativity in writing poetry using picture; and motivate students regarding the importance of the writing, and develop literature like poetry. The targets of this dedication activity were 30 students in SMPN Kota Baru Kefamenanu. This training was implemented through two methods, there are communicative method and action method. Communicative method was used to explain the topics like essence of poetry, and how to create poetry. Action method was used to practice writing a poetry based on observation results of the provided picture. The anthusiasm from the participants, the supports from the head masters and co-teachers, and the financial support from LPPM are helpful in accomplishing this dedication. As a result, the ability of students of grade VII in SMPN Kota Baru Kefamenanu in creating a poetry especialy using picture is at medium category with average score 67.
\end{abstract}

Keywords: writing, poetry, writing poetry, and picture media. 


\section{PENDAHULUAN}

Bahasa Indonesia adalah salah satu mata pelajaran yang terdapat dalam muatan isi kurikulum tingkat sekolah menengah pertama (SMP). Hal ini menunjukkan bahwa bahasa Indonesia memiliki peran yang sangat penting dalam kehidupan bermasyarakat di seluruh Indonesia. Salah satu peran atau fungsi bahasa Indonesia adalah sebagai alat atau media komunikasi dalam dunia pendidikan di seluruh pelosok Indonesia. Oleh karena itu, bahasa Indonesia terus dipelajari oleh seluruh peserta didik di Indonesia, baik dari tingkat SD, SMP, dan SMA.

Dalam kurikulum, mata pelajaran Bahasa Indonesia yang dipelajari di sekolah terdiri atas empat keterampilan berbahasa (language arts, language skills). Keempat keterampilan berbahasa yang dimaksud, yakni: (1) keterampilan menyimak/mendengarkan (listening skills), (2) keterampilan berbicara (speaking skills), (3) keterampilan membaca (reading skills), (4) keterampilan menulis (writing skills). Setiap keterampilan tersebut saling berhubungan. Setiap keterampilan itu erat sekali berhubungan dengan proses-proses berpikir yang mendasari bahasa. Bahasa seseorang mencerminkan pikirannya. Semakin terampil seseorang berbahasa, semakin cerah dan jelas pikirannya (Dawson dalam Tarigan, 2008:1).

Dalam implementasinya di sekolah, keempat keterampilan berbahasa yang telah disebutkan di atas tidak hanya mengarah pada pembelajaran bahasa, tetapi juga mengarah ke pembelajaran sastra. Oleh karena itu, di sekolah dikenal dengan nama mata pelajaran Bahasa dan Sastra Indonesia. Pembelajaran sastra diarahkan pada usaha untuk menimbulkan penghargaan terhadap hasil cipta manusia Indonesia hal ini juga tercantum dalam standar kompetensi mata pelajaran sastra Indonesia berorientasi pada hakekat pembelajaran sastra yaitu sastra adalah belajar menghargai manusia dan nilai-nilai kemanusiaannya.Pembelajaran sastra dapat memberikan pencerahan batin kepada siswa dan melalui pembelajaran sastra juga siswa dapat merasakan dan seakan mengalami berbagai peristiwa yang dibuat pengarang dalam sebuah karya sastra yang sarat dengan nilai-nilai moral sehingga siswa akan kaya dengan nilai-nilai kehidupan. Nilai-nilai kehidupan ini pada akhirnya akan meningkatkan kepekaan perasaan siswa terhadap kehidupan di sekitarnya sehingga membentuk pribadi yang berbudi perkerti luhur.

Salah satu bentuk karya sastra yang diajarkan kepada siswa di sekolah menengah pertama (SMP) adalah puisi. Puisi merupakan bentuk karya sastra yang mengungkapkan pikiran dan perasaan penyair secara imajinatif dan disusun dengan mengkonsentrasikan semua kekuatan bahasa dengan pengkonsentrasian struktur fisik dan srtuktur batin(Waluyo, 1991:25). Penyair mencurahkan segala perasaan dan pikirannyadalam bentuk puisi. Pikiran dan perasaan itu diramu dengan memanfaatkan kreativitas penyair kemudian diwujudkan melalui medium bahasa. Bahasa yang digunakan pun khas, berbeda dengan bahasa yang dipakai dalam drama dan fiksi karena penyair ingin mengekspresikan pengalaman jiwanya secara padat dan intens. Untuk itu, penyair memanfaatkan diksi, arti denotatif dan konotatif, bahasa kiasan, citraan, sarana retorika, faktor kebahasaan dan hal-hal yang berhubungan dengan struktur kata-kata atau kalimat dalam puisinya (Pradopo, 2005: 48).

Menulis merupakan keterampilan produktif dengan menggunakan tulisan. Menulis dapat dikatakan suatu keterampilan berbahasa yang paling rumit di antara keterampilan berbahasa yang lainnya, ini karena menulis bukanlah sekedar menyalin kata-kata dan kalimat-kalimat melainkan juga mengembangkan dan menuangkan pikiran- 
pikirandalamsuatu struktur tulisan yang teratur. Untuk menarik minat siswa dalam menulis sebuah karya sastra terutama dalam menulis puisi diperlukan suatu upaya yang tepat untuk merangsang dan memancing kreativitas siswa. Salah satu cara untuk menarik minat siswa dalam menulis puisi adalah menggunakan media gambar. Media gambar dapat mempermudah, memperlancar, dan membantu siswa dalam menuangkan ide atau pikirannya dalam bentuk puisi.

Media gambar adalah media yang dipergunakan untuk memvisualisasikan atau menyalurkan pesan dari sumber ke penerima (siswa). Pesan yang akan disampaikan dituangkan ke dalam komunikasi visual, di samping itu media gambar berfungsi pula untuk menarik perhatian, memperjelas sajian ide, mengilustrasikan atau menghiasi fakta yang mungkin akan cepat dilupakan atau diabaikan bila tidak digrafiskan. Media gambar pada dasarnya membantu mendorong para siswa dan dapat membangkitkan minatnya pada pelajaran. Dalam kemampuan berbahasa, kegiatan seni dan pernyataan kreativitas bercerita, dramatisasi, bacaan, penulisan, melukis dan menggambar serta menafsirkan dan mengingat isi materi bacaan dari buku teks (Arif S. Sadiman 1984).

Menulis puisi merupakan sebuah kenikmatan seni sastra. Menulis sendiri pada hakekatnya adalah upaya mengekspresikan apa yang dilihat, dialami, dirasakan dan dipikirkan kedalam bahasa tulisan (Arief Hakim, 2004:15). Kegiatan apresiasi sastra yang berjalan di sekolah belum maksimal karena apresiasi yang berjalan di sekolah masih terfokus pada pedoman lama dan terpaku oleh sistem tanpa mengembangkannya sesuai dengan kemampuan yang dimiliki dan realitas yang dihadapi peserta didik dalam kelas. Oleh karena itu, siswa merasa menulis merupakan kegiatan yang sangat sulit untuk dilakukan.

Berdasarkan uraian di atas, penulis akan memberikan pelatihan menulis karya sastra berbentuk puisi. Dalam pelatihan menulis puisi, penulis menggunakan media gambar. Penulis berasumsi bahwa dengan menggunakan media gambar yaitu siswa diajak untuk mengamati gambar yang ditampilkan, kemudian diekspresikan dengan menggunakan kata-kata, maka siswa akan menjadi lebih mudah menuangkan pemikirannya dalam bentuk tulisan seperti puisi.

Kegiatan pengabdian pada masyarakat ini bertujuan: (1) memberikan pengetahuan dan penjelasan kepada siswa di SMP Negeri Kota Baru Kefamenanu mengenai menulis puisi dengan media gambar; (2) memberikan pengetahuan dan penjelasan kepada siswa di SMP Negeri Kota Baru Kefamenanu mengenai langkah-langkah menulis puisi dengan media gambar; (3) meningkatkan kreativitas siswa di SMP Negeri Kota Baru Kefamenanu dalam menulis puisi dengan media gambar; dan (4) memotivasi siswa akan pentingnya menulis dan mengembangkan karya sastra berupa puisi.Kegiatan pengabdian pada masyarakat ini bermanfaat untuk: (1) menambah pengetahuan dan penjelasan mengenai menulis puisi dengan media gambar; (2) siswa/siswi mengetahui langkah-langkah menulis puisi dengan media gambar;(3) siswa/siswi mampu menulis puisidengan media gambar; dan (4) Siswa/siswi memiliki minat dalam hal menulis dan mengembangkan karya sastra berupa puisi.

Masalah yang mendasari pelaksanaan kegiatan pengabdian ini adalah siswa-siswi kelas VII SMP Negeri Kota Baru Kefamenanu merasa sulit dan belum bisa menulis puisi dengan baik. Oleh karena itu, alternatif pemecahan masalah sebagai solusi yang digunakan oleh pengabdi dalam kegiatan ini adalah menerapkan media gambar untuk menulis puisi. Out 
putpelaksanaankegiatan pengabdian pada masyarakat ini, yaitu: (1) siswa/siswi menghasilkan karya tulis berupa puisi dengan media gambar dan (2) siswa/siswi mengapresiasikan karya tulis puisi dengan media gambar.

\section{METODE}

Pelaksanaan kegiatan pengabdian pada masyarakat ini bertempat di SMP Negeri Kota Baru Kefamenanu. Waktu pelaksanaan pengabdian pada hari Senin, 23 Juli 2018 - Selasa, 24 Juli 2018. Alat yang digunakan selama kegiatan adalah laptop, LCD, media gambar, dan kamera.Bahan yang digunakan selama kegiatan adalah spanduk, materi pelatihan serta notebook dan pulpen untuk semua peserta.Pelaksanaan kegiatan pengabdian pada masyarakat ini, menggunakan metode berupa pelatihan menulis puisi dengan tahap: (1) memberikan pengetahuan mengenai keterampilan berbahasa yaitu menulis dan apresiasi sastra berupa puisi; (2) memberikan pengetahuan mengenai langkah-langkah dalam proses pemikiran kreatif untuk menulis puisi; (3) memberikan penjelasan kepada siswa mengenai menulis puisi dengan media gambar; (4) menampilkan gambar yang dijadikan sebagai media dalam menulis puisi; (5) membimbing dan mengarahkan siswa menulis puisi dengan media gambar; (6) Hasil pekerjaan siswa berupa puisi yang telah dibuat berdasarkan media gambar, dikumpulkan dan selanjutnya dianalisis.

\section{HASIL DAN PEMBAHASAN}

Berdasarkan hasil pelaksanaan pengabdian di SMP Negeri Kota Baru terkait "Menulis Puisi dengan Media Gambar, terdapat 30 orang siswa yang terlibat dalam pelakanaan kegiatan. Dengan demikian, dapat dipastikan bahwa jumlah pekerjaan terjaring dalam kegiatan pengabdian ini adalah sebanyak 30 karangan dalam bentuk puisi. Pada saat pelaksanaan kegiatatan, tim pengabdi, yakni Joni S. Nalenan, S.Pd., M.Hum. dan Nurtang, S.Pd., M.Hum. sebagai pelaksana tindakan, melaksanakan skenario tindakan yang telah direncanakan dan mencatat kegiatan siswa melalui jurnal pembelajaran. Tim pengabdi pun dibantu oleh 2 orang pembantu lapangan, yakni Klaudius Agusta Sanbein dan Benediktus Sese.

Tim Pengabdi mengawali kegiatan pengabdian di kelas dengan mengucapkan salam pembuka dan menyampaikan materi yang akan dibahas. Selanjutnya guru mengajukan pertanyaan yang berkaitan dengan menulis puisi dan memberikan stimulus pada siswa agar dapat menyebutkan bahwa menulis puisi dapat dilakukan dengan berbagai cara (misalnya melalui kejadian yang pernah dialami, pengalaman yang menarik dan pemandangan alam), serta guru mengadakan umpan balik untuk mengetahui sejauh mana pengetahuan siswa tentang menulis puisi.

Pada tahap inti pelaksanaan pengabdian, tim pengabdi menyampaikan materi pembelajaran. Setelah itu, menanyakan kembali materi yang telah disampaikan lalu memberikan kesempatan pada siswa untuk bertanya tentang hal yang belum dipahami dari materi yang telah disampaikan. Selanjutnya, tim pengabdi menampilkan gambar yang menjadi objek penulisan puisi siswa dan menanyakan objek/fakta apa saja yang terdapat dalam gambar yang ditampilkan. Setelah itu, tim pengabdi menyampaikan fungsi gambar dalam penulisan puisi lalu memberikan kesempatan kepada siswa untuk mulai menulis puisi dengan mencermati gambar yang ditampilkan. Pada tahap akhir pembelajaran, tim pengabdi 
mengumpulkan puisi yang telah ditulis siswa lalu bersama siswa menyimpulkan pembelajaran saat itu dan menutup kegiatan pembelajaran. Setelah itu, tim Pengabdi menilai pekerjaan siswa berupa puisi yang dikumpulkan. Hasil penilaian puisi siswa disajikan dalam Tabel 1.

Tabel 1. Hasil Penilaian KaranganSiswa dalam Bentuk Puisi

\begin{tabular}{|c|c|c|c|c|c|c|c|c|}
\hline \multirow{3}{*}{ No } & \multirow{3}{*}{$\begin{array}{l}\text { Kode } \\
\text { Nama } \\
\text { Siswa }\end{array}$} & \multicolumn{7}{|c|}{ Skor penilaian } \\
\hline & & Judul & Diksi & $\begin{array}{l}\text { Kesesuaian } \\
\text { tema dengan } \\
\text { isi puisi }\end{array}$ & Pengimajian & Amanat & Jml Skor & Nilai \\
\hline & & $\begin{array}{c}\text { Skor } \\
\text { maks } 5\end{array}$ & $\begin{array}{c}\text { Skor } \\
\text { maks } 5\end{array}$ & Skor maks 5 & Skor maks 5 & $\begin{array}{c}\text { Skor maks } \\
5\end{array}$ & $\begin{array}{c}\text { Skor maks } \\
25\end{array}$ & $\begin{array}{c}\text { Nilai maks } \\
100\end{array}$ \\
\hline 1 & MGE & 4 & 5 & 4 & 4 & 3 & 20 & 80 \\
\hline 2 & FOA & 4 & 5 & 4 & 4 & 4 & 20 & 84 \\
\hline 3 & JFDK & 3 & 3 & 4 & 3 & 2 & 15 & 60 \\
\hline 4 & AEB & 4 & 4 & 4 & 4 & 3 & 19 & 76 \\
\hline 5 & MPNN & 3 & 3 & 3 & 3 & 2 & 14 & 56 \\
\hline 6 & AMO & 4 & 4 & 4 & 4 & 3 & 19 & 76 \\
\hline 7 & FJK & 3 & 3 & 3 & 3 & 2 & 14 & 56 \\
\hline 8 & MGS & 3 & 3 & 4 & 3 & 2 & 15 & 60 \\
\hline 9 & MMT & 4 & 4 & 3 & 3 & 4 & 18 & 72 \\
\hline 10 & MDPS & 3 & 3 & 4 & 3 & 2 & 15 & 60 \\
\hline 11 & TMN & 3 & 4 & 4 & 3 & 4 & 18 & 72 \\
\hline 12 & EAWP & 4 & 4 & 4 & 3 & 3 & 17 & 70 \\
\hline 13 & GYU & 3 & 4 & 3 & 3 & 2 & 15 & 60 \\
\hline 14 & JBRH & 4 & 3 & 3 & 3 & 2 & 15 & 60 \\
\hline 15 & RP & 4 & 2 & 2 & 3 & 3 & 14 & 56 \\
\hline 16 & SFR & 3 & 4 & 4 & 3 & 4 & 18 & 72 \\
\hline 17 & EYSM & 3 & 3 & 2 & 3 & 3 & 14 & 56 \\
\hline 18 & JMAR & 4 & 3 & 4 & 4 & 3 & 18 & 72 \\
\hline 19 & $\mathrm{AK}$ & 3 & 3 & 3 & 3 & 3 & 15 & 60 \\
\hline 20 & YK & 3 & 2 & 2 & 4 & 3 & 14 & 56 \\
\hline 21 & DAR & 4 & 4 & 4 & 4 & 3 & 19 & 76 \\
\hline 22 & $\mathrm{JMH}$ & 4 & 4 & 3 & 4 & 3 & 18 & 72 \\
\hline 23 & RSK & 4 & 3 & 2 & 3 & 3 & 15 & 60 \\
\hline 24 & RAR & 4 & 5 & 4 & 4 & 3 & 20 & 80 \\
\hline 25 & ADS & 4 & 3 & 3 & 3 & 3 & 16 & 64 \\
\hline 26 & YVK & 4 & 3 & 4 & 4 & 3 & 18 & 72 \\
\hline 27 & ATSB & 4 & 4 & 3 & 3 & 4 & 18 & 72 \\
\hline 28 & DCT & 4 & 3 & 2 & 3 & 3 & 15 & 60 \\
\hline 29 & SDK & 4 & 4 & 4 & 4 & 4 & 20 & 80 \\
\hline 30 & AT & 3 & 4 & 3 & 3 & 3 & 16 & 64 \\
\hline & imlah & 108 & 106 & 100 & 101 & 89 & 502 & 2014 \\
\hline & erata & 72 & 71 & 67 & 67 & 59 & 67 & 67 \\
\hline
\end{tabular}

Berdasarkan Tabel 1 penilaian hasil karangan siswa di atas, terlihat jelas bahwa ada lima unsur penilaian dalam pembelajaran menulis puisi dengan media gambar, yakni judul, 
diksi, kesesuaian tema dengan isi, pengimajian, dan amanat. mencapai nilai 72 dengan jumlah skor keseluruhan 108. Rerata kemampuan siswa dalam menentukan diksi puisi sesuai dengan media gambar yang ditampilkan mencapai nilai 71 dengan jumlah skor keseluruhan 106. Rerata kemampuan siswa dalam menyesuaikan tema puisi dengan isi puisi sesuai dengan media gambar yang ditampilkan mencapai nilai 67 dengan jumlah skor keseluruhan 100 . Rerata kemampuan siswa dalam berimaji untuk puisi sesuai dengan media gambar yang ditampilkan mencapai nilai 67 dengan jumlah skor keseluruhan 101. Rerata kemampuan siswa dalam menampilkan amanat puisi sesuai dengan media gambar yang ditampilkan mencapai nilai 59 dengan jumlah skor keseluruhan 89. Secara keseluruhan kemampuan siswa kelas VIII SMP Negeri Kota Baru dalam menulis puisi dengan media gambar mencapai nilai 67 dengan jumlah skor 2014 termasuk dalam kategori cukup.Rerata kemampuan siswa dalam menentukan diksi puisi sesuai dengan media gambar yang ditampilkan mencapai nilai 71 dengan jumlah skor keseluruhan 106. Rerata kemampuan siswa dalam menyesuaikan tema puisi dengan isi puisi sesuai dengan media gambar yang ditampilkan mencapai nilai 67 dengan jumlah skor keseluruhan 100. Rerata kemampuan siswa dalam berimaji untuk puisi sesuai dengan media gambar yang ditampilkan mencapai nilai 67 dengan jumlah skor keseluruhan 101. Rerata kemampuan siswa dalam menampilkan amanat puisi sesuai dengan media gambar yang ditampilkan mencapai nilai 59 dengan jumlah skor keseluruhan 89 . Secara keseluruhan kemampuan siswa kelas VIII SMP Negeri Kota Baru dalam menulis puisi dengan media gambar mencapai nilai 67 dengan jumlah skor 2014 termasuk dalam kategori cukup.

Tingkat penguasaan siswa kelas VIII SMP Negeri Kota Baru dalam menulis puisi melalui media gambar dengan interval 80 - 100 dengan kategori baik sekali sebanyak 4 orang siswa sehingga persentase tingkat penguasaan hanya mencapai $13,33 \%$. Tingkat penguasaan siswa dalam menulis puisi melalui media gambar dengan interval $70-79$ dengan kategori baik sebanyak 11 orang siswa sehingga persentase tingkat penguasaan mencapai $36,67 \%$. Tingkat penguasaan siswa dalam menulis puisi melalui media gambar dengan interval $60-$ 69 dengan kategori cukup baik sebanyak 10 orang siswa sehingga persentase tingkat penguasaan mencapai $33,33 \%$. Tingkat penguasaan siswa dalam menulis puisi melalui media gambar dengan interval $0-59$ dengan kategori kurang baik sebanyak 5 orang siswa sehingga persentase tingkat penguasaan mencapai $16,67 \%$.

\section{SIMPULAN DAN IMPLIKASI}

\section{Simpulan}

Kegiatan pengabdian berupa pelatihan menulis puisi dengan media gambar pada siswa kelas VIII SMPN Kota Baru dapat diselenggarakan dengan baik dan berjalan lancar sesuai dengan rencana kegiatan yang telah disusun. Tujuan dan out put yang dihasilkan sesuai dengan apa yang diinginkan/direncanakan dari kegiatan pengabdian ini. Secara keseluruhan, kemampuan siswa kelas VIII SMPN Kota Baru dalam menulis puisi khususnya melalui media gambar cukup baik dengan rerata nilai 67. 


\section{UCAPAN TERIMA KASIH}

Pengabdi menyadari bahwa dalam pelaksanaan pengabdian ini, mendapat bantuan dari berbagai pihak baik secara moril maupun material. Oleh karena itu, pengabdi mengucapakan terima kasih kepada:

1. Universitas Timor (Unimor) terkhususnya Kepala LP2M dan Staf yang sudah mendanai kegiatan pengabdian ini secara utuh dengan sumber dana Hibah Unimor.

2. Kepala Sekolah Menengah Pertama Negeri Kota Baru Kefamenanu dan Seluruh Dewan Guru yang berkenan dan memberikan kesempatan kepada pengabdi dalam menjalankan pengabdian.

3. Siswa-siswi SMP Negeri Kota Baru Kefamenanu yang dengan begitu antusian mengikuti kegiatan pengabdian ini dengan baik.

4. Pihak-pihak lain yang tidak sempat disebutkan secara rinci yang sudah berkontribusi atau membantu dalam pelaksanaan pengabdian ini.

\section{DAFTAR PUSTAKA}

Arief, M. 2004. Kiat Menulis Artikel di Media Dari Pemula Sampai Akhir. Bandung : Nuansa Cendikia.

Endraswara, Suwardi. 2005. Metode dan Teori Pengajaran Sastra.Yogyakarta: Buana Pustaka.

Pradopo, Rachmat Djoko. 2005. Pengkajian Puisi. Yogyakarta: Gajah Mada University Press.

Situmorang. 1983. Puisi Teori Apresiasi Bentuk dan Struktur. Ende-Flores: Nusa Indah.

Waluyo, Hermanj. 2002. Apresiasi puisi. Jakarta: Gramedia Pustaka Utama. 